\title{
Biological characteristics and parasitism capacity of Trichogramma pretiosum Riley (Hymenoptera, Trichogrammatidae) on eggs of Spodoptera frugiperda (J. E. Smith) (Lepidoptera, Noctuidae)
}

\author{
Regiane Cristina Oliveira de Freitas Bueno ${ }^{1}$, Adeney de Freitas Bueno², José Roberto Postalli Parra 3 , \\ Simone Silva Vieira ${ }^{4} \&$ Luciele Januário de Oliveira ${ }^{5}$
}

${ }^{1}$ Universidade de Rio Verde, FESURV, 75901-970 Rio Verde-GO, Brasil. regianecrisoliveira@gmail.com.

${ }^{2}$ Embrapa Soja, Rodovia Carlos João Strass, s/n, Caixa postal 231 - Distrito de Warta, 86001-970 Londrina-PR, Brasil. adeney@cnpso.embrapa.br. (Author for correspondence)

${ }^{3}$ Departamento de Entomologia, Fitopatologia e Zoologia Agrícola, Escola Superior de Agricultura "Luiz de Queiroz”, Universidade de São Paulo, Caixa Postal 9, 13418-900 Piracicaba-SP, Brasil. jrpparra@esalq.usp.br

${ }^{4}$ Centro de Ciências Agroveterinárias, Universidade do Estado de Santa Catarina, 88520-000 Lages-SC, Brasil. ssilva@hotmail.com

${ }^{5}$ Centro Federal de Educação Tecnológica de Rio Verde, Rodovia Sul Goiana Km 1, 759000-000 Rio Verde-GO, Brasil. luciellejanuario@yahoo.com.br

\begin{abstract}
Biological characteristics and parasitism capacity of Trichogramma pretiosum Riley (Hymenoptera, Trichogrammatidae) on eggs of Spodoptera frugiperda (J. E. Smith) (Lepidoptera, Noctuidae). This study aimed at evaluating the biological characteristics and the capacity of parasitism of a Trichogramma pretiosum Riley, 1869 (Hymenoptera, Trichogrammatidae) strain (T. pretiosum RV) collected in Rio Verde County, State of Goiás, Brazil. The study was carried out on eggs of Spodoptera frugiperda (J. E. Smith, 1797) (Lepidoptera, Noctuidae) and conducted under controlled environmental conditions at different constant temperatures. The biological parameters determined were: developmental time (egg-adult; days); emergence (\%); sex ratio; number of progeny/egg; number of generation/year; thermal constant (K); temperature threshold (Tb); daily number of parasitized eggs; cumulative parasitism (\%); total number of eggs parasitized by T. pretiosum; and female longevity. To study the T. pretiosum parasitism capacity, $20 \mathrm{~S}$. frugiperda eggs ( $\leq 24 \mathrm{~h}$ old) were placed into $8.0 \mathrm{~cm}$ x $2.0 \mathrm{~cm}$ glass vials containing one female $(\leq 24 \mathrm{~h}$ old $)$ each. Trials were carried out in a completely randomized experimental design, with 20 replications at each temperature. The environmental chambers (BOD type) were set at $18^{\circ} \mathrm{C}, 20^{\circ} \mathrm{C}, 22^{\circ} \mathrm{C}, 25^{\circ} \mathrm{C}, 28^{\circ} \mathrm{C}$ and $32^{\circ} \mathrm{C} \pm 1^{\circ} \mathrm{C}, 70 \pm 10 \%$ relative humidity, and 14/10 h (L:D) photoperiod. The eggs of $S$. frugiperda were replaced daily until parasitoid death. Results have shown an inverse correlation between developmental time and temperature, with statistically significant differences among means, except at $25^{\circ} \mathrm{C}$ and $28^{\circ} \mathrm{C}$ (10 days). Parasitoid emergence (\%) was also influenced by temperature. The lowest percent emergence was observed at $32^{\circ} \mathrm{C}$, and the highest ones at $18^{\circ} \mathrm{C}$ and $20^{\circ} \mathrm{C}$ temperatures. The temperature did not affect $T$. pretiosum sex ratio and number of parasitoids per egg, thus allowing changes in the temperature to control insect mass production in the laboratory to meet the needs for field releases.
\end{abstract}

KEYWORDS. Biological control; egg parasitoids; fall armyworm; temperature.

RESUMO. Características biológicas e capacidade de parasitismo de Trichogramma pretiosum Riley (Hymenoptera, Trichogrammatidae) em ovos de Spodoptera frugiperda (J. E. Smith) (Lepidóptera, Noctuidae). O objetivo deste estudo foi avaliar as características biológicas e a capacidade de parasitismo de uma linhagem de Trichogramma pretiosum Riley, 1869 (Hymenoptera, Trichogrammatidae), coletada em Rio Verde, Goiás, Brasil (T. pretiosum RV). O estudo foi feito com ovos de Spodoptera frugiperda (J. E. Smith) (Lepidóptera, Noctuidae) e conduzido sob condições ambientais controladas e em diferentes temperaturas constantes. Os parâmetros biológicos determinados foram: período de desenvolvimento (ovo-adulto; dias); emergência (\%); razão sexual; número de progênie/ovo; número de gerações/ano; constante térmica (K); temperatura base (Tb); número de ovos parasitados diariamente; parasitismo acumulado (\%); número total de ovos parasitados por fêmea de T. pretiosum; e longevidade das fêmeas. Para estudar a capacidade de parasitismo de $T$. pretiosum, 20 ovos de $S$. frugiperda ( $\leq 24 \mathrm{~h}$ de idade) foram colocados em tubos de vidro $(8,0 \times 2,0 \mathrm{~cm})$ contendo uma fêmea $(\leq 24 \mathrm{~h}$ de idade) cada. Os experimentos foram conduzidos em delineamento experimental inteiramente casualizado, com 20 repetições por temperatura. As BODs foram reguladas para temperaturas constantes de $18^{\circ} \mathrm{C}$, $20^{\circ} \mathrm{C}, 22^{\circ} \mathrm{C}, 25^{\circ} \mathrm{C}, 28^{\circ} \mathrm{C}$ e $32^{\circ} \mathrm{C}$, umidade relativa de $70 \pm 10 \%$ e fotoperíodo de $14 / 10 \mathrm{~h}$ (L:E). Os ovos de S. frugiperda foram substituídos diariamente até a morte do parasitóide. Os resultados mostraram uma relação inversa entre o tempo de desenvolvimento e a temperatura, com médias apresentado diferenças estatisticamente significativas entre si, com exceção das temperaturas de $25^{\circ} \mathrm{C}$ e $28^{\circ} \mathrm{C}$ (10 dias). A emergência do parasitóide (\%) também foi influenciada pela temperatura. A menor porcentagem de emergência foi observada a $32^{\circ} \mathrm{C}$ e a maior nas temperaturas de $18^{\circ} \mathrm{C}$ e $20^{\circ} \mathrm{C}$. A temperatura não alterou a razão sexual nem o número de parasitóides por ovo, permitindo mudanças na temperatura para controlar a produção de insetos em laboratório, com o fim de atender às necessidades das liberações no campo.

PALAVRAS-CHAVE. Controle biológico; lagarta do cartucho; parasitóides de ovos; temperatura.

The fall armyworm, Spodoptera frugiperda (J. E. Smith, 1797) (Lepidoptera, Noctuidae), is the most important insect pest of corn in Brazil as well as in many other countries around the world. The larvae feed on corn plants throughout the whole plant cycle. The young larvae cause damage by scratching the leaf surface. In later plant growth stages, however, the larvae burrow into the plant whorl and cause severe defoliation (Cruz 2002). This pest alone may cause more than 34\% reduction in corn production in Brazil (Cruz \& Turpin 1982; Cruz et al. 1996). S. frugiperda is a main pest 
on corn, but since it is polyphagous, it may attack and damage many other crops such as rice, sorghum (Sparks 1979), and soybean (Luginbill 1928), among others.

The control of $S$. frugiperda relies mainly on insecticides, which have actually been overused over the recent years, resulting on insect resistance to the most commonly used products, as well as causing environmental contamination (Diez-Rodrigues \& Omoto 2001). The only way to mitigate this problem is the implementation of an Integrated Pest Management (IPM) program in which biological control will be an important component.

Egg parasitoids of the genus Trichogramma (Hymenoptera, Trichogrammatidae) used as a biological control practice tool have shown efficient results in controlling lepidopteran pest outbreaks (Parra et al. 1987). Some of the good characteristics of the genus Trichogramma responsible for its wide use in biological control programs are: easily reared on alternative hosts (Parra 1997; Haji et al. 1998); highly aggressive in parasitizing eggs of different lepidopteran pest species (Botelho 1997), among others. Studies with Trichogramma have been carried out in more than 50 countries and commercial releases are successfully performed in approximately 32 million hectares every year (Smith 1996). The success of Trichogramma releases depends, among other factors, on the knowledge of the biological characteristics of the parasitoid species and/or strain to be used and on its interaction with the specific target host, since those characteristics will determine whether or not the parasitoid will efficiently control the targeted pest species (Bourchier \& Smith 1996). Therefore, to better evaluate the effects of the use of a Trichogramma species or strain in biological control programs, it is required previous laboratory studies to evaluate the parasitoid biology, parasitism capacity, parasitoid emergence, and parasitoid biological cycle, among other biological characteristics (Hassan 1997; Scholler \& Hassan 2001). It is also important to determine the thermal requirements to estimate the ideal temperature for parasitoid development. This factor is very important in planning parasitoid mass rearing in the laboratory, since through thermal requirements it is possible to predict the day the parasitoid will emerge, thus allowing the insect production in the laboratory to meet field releases needs (Haddad et al. 1999). However, it is also important to bear in mind that those biological features might vary deeply among species or strains, and accordingly to hosts and temperature as well (Hassan 1997; Scholler \& Hassan 2001).

A T. pretiosum strain collected in Rio Verde County, State of Goiás, Central Brazil, designated as T. pretiosum RV, was found to be highly aggressive against Pseudoplusia includens Walker, 1857 (Lepidoptera, Noctuidae). This species is an important pest that has recently caused outbreaks on different field crops such as soybean and cotton (Bueno et al 2009). The concomitant occurrence of S. frugiperda and P. includens on those crops is rather common. Therefore, studies on biological parameters of that parasitoid on both hosts are very important. Bueno (2008) has already studied the effect of T. pretiosum RV on P. includens and Anticarsia gemmatalis Hübner, 1818 (Lepidoptera, Noctuidae). However, up to nowadays no data on its effect on S. frugiperda are yet available.
Consequently, this research work was carried out to study the biological characteristics as well as the parasitism capacity of the T. pretiosum RV strain on S. frugiperda eggs, at different temperatures in order to obtain data to provide support to a future biological control program developed for the $\mathrm{S}$. frugiperda management, using this strain, which is able to control different insect pest species under field conditions.

\section{MATERIAL AND METHODS}

S. frugiperda rearing. The insects were reared on artificial diet (Greene et al. 1976) under controlled environmental conditions $\left[25 \pm 2^{\circ} \mathrm{C}\right.$ temperature, $70 \pm 10 \% \mathrm{RH}, 14 / 10 \mathrm{~h}$ (L:D) photoperiod]. After emergence, adults were fed with a $10 \%$ honey solution, inside $10 \mathrm{~cm}$ in diameter $\mathrm{x} 21.5 \mathrm{~cm}$ in height cages, which had their inner walls covered with $\mathrm{A}_{4}$ paper. Egg masses produced in these cages were then removed and used either in the trials or to maintain the insect colonies.

T. pretiosum rearing. The parasitoid rearing was conducted according to the methodology described by Parra (1997). Eggs of Anagasta kuehniella (Zeller, 1879) (Lepidoptera, Pyralidae) were glued on cardboard, turned sterile by exposing them to ultraviolet light (Stein \& Parra 1987), and then proffered to parasitism for $24 \mathrm{~h}$. The wasps obtained by this process were then reared for one generation on $S$. frugiperda eggs prior to field trials to avoid the possible conditioning effects of rearing on a factitious host.

Biological characteristics of $T$. pretiosum. Twenty $T$. pretiosum females $(\leq 24 \mathrm{~h}$ old $)$ were individualized into glass vials (12 mm diameter x $75 \mathrm{~mm}$ height) containing $20 \mathrm{~S}$. frugiperda eggs $(\leq 24 \mathrm{~h}$ old $)$ and then kept into controlled environmental chambers $\left[25 \pm 1^{\circ} \mathrm{C}\right.$ temperature, $70 \pm 10 \% \mathrm{RH}$, 14/10 h (L:D) photoperiod]. After 24 hours, the parasitoids were removed and the vials were placed into environmental chambers set at $18^{\circ} \mathrm{C}, 20^{\circ} \mathrm{C}, 22^{\circ} \mathrm{C}, 25^{\circ} \mathrm{C}, 28^{\circ} \mathrm{C}, 30^{\circ} \mathrm{C}$, and $32 \pm 1^{\circ} \mathrm{C}$ temperature, $70 \pm 10 \% \mathrm{RH}, 14 / 10 \mathrm{~h}$ (L:D) photoperiod. The parameters evaluated were developmental time (egg to adult; days), emergence (\%), sex ratio [female/(female + male)], number of progeny/host egg, number of generation/ year, total parasitized eggs/female, longevity (days).

The experiment was carried out on a complete randomized experimental design with seven treatments (temperature) and 20 replicates per temperature. Results were computed to evaluate normality of residues, homogeneity of treatment variance, and addictiveness of model. ANOVA was performed with transformed data, whenever necessary. Means were compared by Tukey test $(\mathrm{P} \leq 0.05)$.

Basic thermal threshold $(\mathrm{Tb})$ (expressed in Celsius degrees) and thermal constant (K) (expressed in degreedays) were computed by applying the hyperbolic method (Haddad et al. 1995) based on the parasitoid developmental time at the established temperatures (from $18^{\circ} \mathrm{C}$ to $32 \pm 1^{\circ} \mathrm{C}$ ), on eggs of $S$. frugiperda. The number of $T$. pretiosum annual generations were estimated using the following equation: $\mathrm{NG}=\{\mathrm{T}(\mathrm{Ts}-\mathrm{Tb}) / \mathrm{K}\}$, where: $\mathrm{K}=$ thermal constant, $\mathrm{Ts}=$ the studied temperature, $\mathrm{Tb}=$ lower thermal threshold, and $\mathrm{T}=$ time (days). 
Parasitism capacity of T. pretiosum. Twenty T. pretiosum females $(\leq 24 \mathrm{~h}$ old $)$ were individualized into glass vials (12 mm diameter x $75 \mathrm{~mm}$ height) containing 20 eggs of $S$. frugiperda $(\leq 24 \mathrm{~h}$ old) for each treatment, and then placed inside environmental chambers at $18^{\circ} \mathrm{C}, 20^{\circ} \mathrm{C}, 22^{\circ} \mathrm{C}, 25^{\circ} \mathrm{C}$, $28^{\circ} \mathrm{C}, 30^{\circ} \mathrm{C}$, and $32 \pm 1^{\circ} \mathrm{C}$ temperature, $70 \pm 10 \% \mathrm{RH}, 14 / 10 \mathrm{~h}$ (L:D) photoperiod. Spodoptera frugiperda eggs were daily replaced until death of the female wasp. The number of parasitized eggs per day, cumulative parasitism (\%), total number of parasitized eggs, and female longevity were also determined. Results were computed to evaluate the normality of residues, homogeneity of treatment variance, and addictiveness of model. Data were transformed whenever necessary to perform ANOVA. Means were compared by Tukey test $(\mathrm{P} \leq 0.05)$.

\section{RESULTS}

Biological characteristics of $T$. pretiosum. Data on the mean $T$. pretiosum developmental time from egg to adult (days) were inversely correlated to temperature and were statically different among the treatments, except for $25^{\circ} \mathrm{C}$ and $28^{\circ} \mathrm{C}$ temperatures (Table I). The emergence (\%) of $T$. pretiosum progeny was also influenced by temperature. The lowest emergence rate was at $32^{\circ} \mathrm{C}$ temperature and the highest ones at $18^{\circ} \mathrm{C}$ and $20^{\circ} \mathrm{C}$ temperatures. At $22^{\circ} \mathrm{C}, 25^{\circ} \mathrm{C}, 28^{\circ} \mathrm{C}$, and $30^{\circ} \mathrm{C}$ temperatures, the emergence had an intermediate rate and had no statistically significant differences among them (Table I). Temperature has no effect either on the sex ratio of $T$. pretiosum or on the number of progeny emerging from each $S$. frugiperda egg (Table I). The estimated number of annual generations obtained under laboratory conditions was higher at higher temperatures (Table I). However, $T$. pretiosum did develop under all the temperatures assayed, with a temperature threshold (Tb) of $9.48^{\circ} \mathrm{C}$ and a thermal constant (K) of 164.21 degree days (Fig 1).

Parasitism capacity of $T$. pretiosum. The rhythm of $T$. pretiosum parasitism varied with temperature (Fig 2). The parasitism was concentrated on the first days and during the first 24 hours, the mean host eggs parasitized per females were $4.35,1.75,1.40,6.55,11.45,3.45$, and 5.20 eggs at $18^{\circ}, 20^{\circ} \mathrm{C}, 22^{\circ} \mathrm{C}, 25^{\circ} \mathrm{C}, 28^{\circ} \mathrm{C}, 30^{\circ} \mathrm{C}$, and $32^{\circ} \mathrm{C}$ temperature, respectively (Fig 2). Cumulative parasitism of $80 \%$ or higher were reached after 4 days at $28^{\circ} \mathrm{C}$ and $32^{\circ} \mathrm{C}, 5$ days at $25^{\circ} \mathrm{C}, 8$

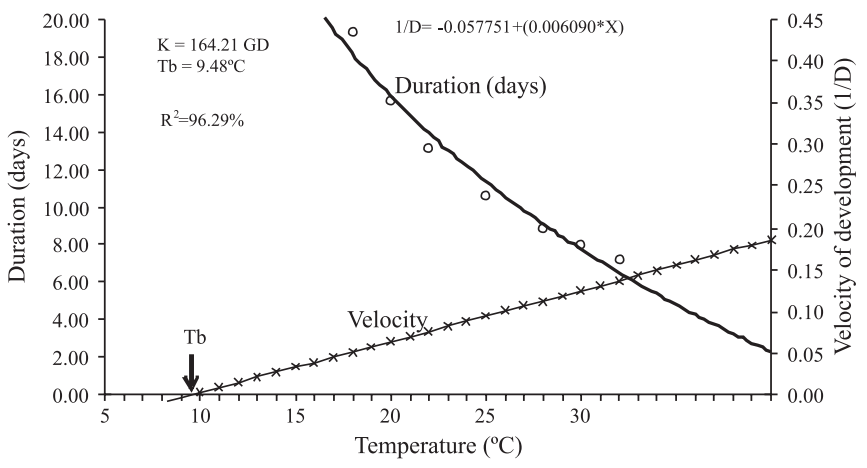

Fig. 1. Curve of development of T. pretiosum RV reared on S. frugiperda eggs at different temperatures $\left[18^{\circ} \mathrm{C}\right.$ to $32^{\circ} \mathrm{C}$ temperature, $70 \pm 10 \% \mathrm{RH}$, 14/10 h (L:D) photoperiod].

days at $20^{\circ} \mathrm{C}, 22^{\circ} \mathrm{C}$ and $25^{\circ} \mathrm{C}$ and 9 days at $18^{\circ} \mathrm{C}$ (Fig 2).

Female longevity decreased as temperature increased, varying from 17.4 to 2.0 days at $18^{\circ} \mathrm{C}$ and $32^{\circ} \mathrm{C}$, respectively. The highest number of parasitized eggs (avg. 30.1) per female was obtained at $28^{\circ} \mathrm{C}$, whereas the lowest number (avg. 7.2) was obtained at $32^{\circ} \mathrm{C}$ (Table II).

\section{DISCUSSION}

Developmental time varied with temperature, showing that the parasitoids may complete the development in seven days when the insects developed at $32^{\circ} \mathrm{C}$ or in 20 days when the insects developed at $18^{\circ} \mathrm{C}$. It is important to bear in mind that knowing this biological parameter allows planning the insect mass production in the laboratory to meet the needs for field releases (Haddad et al. 1999). It is possible because important biological features, such as sex ratio, are not altered by these changes in temperature. At all tested temperatures, parasitoid emergence was always higher than $88 \%$.

The results indicate that these changes in temperature during the parasitoid rearing, apparently, did not altered parasitoid quality. Similar results were reported by Pratissoli \& Parra (2000) for a different strain of T. pretiosum parasitizing eggs of Tuta absoluta (Meyrick) and Phthorimaea operculella (Zeller) (Lepidoptera, Gelechiidae). These authors observed that the sex ratio and emergence were not modified by the variations on temperatures reported in their study. These similarities indicate that $T$. pretiosum is well adapted to the

Table I. Means ( \pm SE) of developmental time (days), emergence (\%), sex ratio, number of progeny per host egg and estimated number of generation per year of T. pretiosum RV reared on S. frugiperda eggs at different temperatures $\left[18^{\circ} \mathrm{C}\right.$ to $32^{\circ} \mathrm{C}$ temperature, $70 \pm 10 \% \mathrm{RH}, 14 / 10 \mathrm{~h}$ (L:D) photoperiod].

\begin{tabular}{cccccc}
\hline $\begin{array}{c}\text { Temperature } \\
{ }^{\circ} \mathrm{C}\end{array}$ & $\begin{array}{c}\text { Developmental time } \\
\text { (egg-adult) }\end{array}$ & $\begin{array}{c}\text { Emergence } \\
(\%)\end{array}$ & $\begin{array}{c}\text { Sex } \\
\text { ratio }\end{array}$ & $\begin{array}{c}\text { Number of progeny/ } \\
\text { egg }\end{array}$ & $\begin{array}{c}\text { Number of generation/ } \\
\text { year }\end{array}$ \\
\hline 18 & $20.0 \pm 0.00 \mathrm{a}$ & $100.00 \pm 0.00 \mathrm{~b}$ & $0.69 \pm 0.01 \mathrm{a}$ & $1.31 \pm 0.02 \mathrm{a}$ & $1.14 \pm 0.01 \mathrm{a}$ \\
20 & $15.0 \pm 0.00 \mathrm{~b}$ & $99.51 \pm 0.30 \mathrm{~b}$ & $0.61 \pm 0.01 \mathrm{a}$ & $1.14 \pm 0.7$ & 23.1 \\
22 & $13.0 \pm 0.00 \mathrm{c}$ & $98.19 \pm 0.25 \mathrm{ab}$ & $0.66 \pm 0.01 \mathrm{a}$ & $1.31 \pm 0.02 \mathrm{a}$ & 27.4 \\
25 & $10.0 \pm 0.00 \mathrm{~d}$ & $98.42 \pm 0.29 \mathrm{ab}$ & $0.70 \pm 0.01 \mathrm{a}$ & $1.29 \pm 0.02 \mathrm{a}$ & 34.0 \\
28 & $10.0 \pm 0.00 \mathrm{~d}$ & $96.27 \pm 0.66 \mathrm{ab}$ & $0.67 \pm 0.01 \mathrm{a}$ & $1.03 \pm 0.01 \mathrm{a}$ & 40.6 \\
30 & $8.0 \pm 0.00 \mathrm{e}$ & $93.78 \pm 0.82 \mathrm{ab}$ & $0.70 \pm 0.01 \mathrm{a}$ & $1.21 \pm 0.01 \mathrm{a}$ & 45.0 \\
32 & $7.0 \pm 0.00 \mathrm{f}$ & $88.91 \pm 0.87 \mathrm{a}$ & $0.61 \pm 0.01 \mathrm{a}$ & $1.02 \pm 0.01 \mathrm{a}$ & 49.4 \\
\hline
\end{tabular}

Means followed by the same letter in the column are not statistically different according to the Tukey test (P>0.05) 

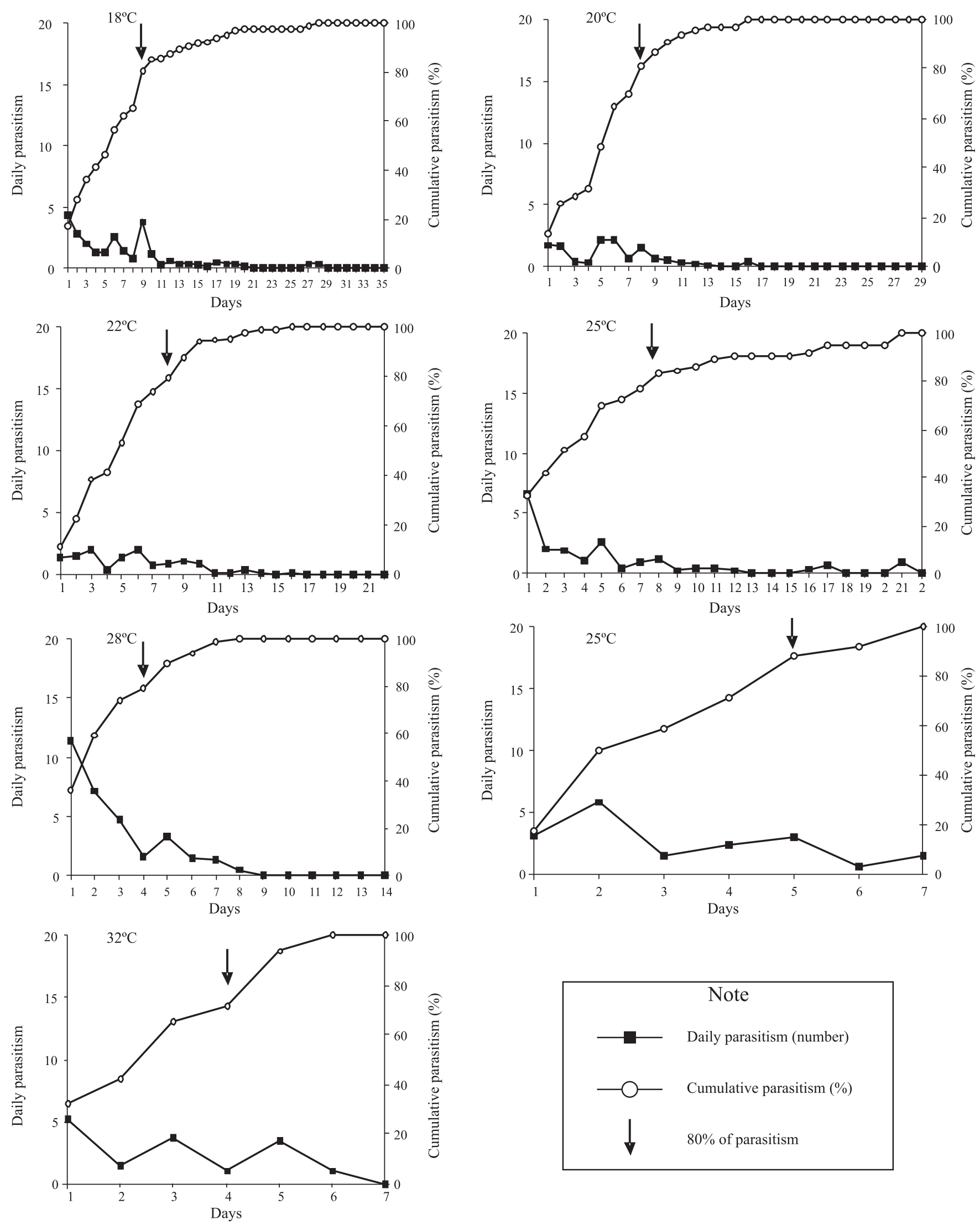

Fig. 2. Daily mean number and cumulative parasitism of T. pretiosum RV on $S$. frugiperda eggs at different temperatures $\left[18^{\circ} \mathrm{C}\right.$ to $32^{\circ} \mathrm{C}$ temperature, $70 \pm 10 \%$ RH, 14/10 h (L:D) photoperiod]. 
studied temperature range. T. pretiosum is also adapted to different lepidopteran host eggs such as $S$. frugiperda eggs, mainly considering that the parasitoid emergence (\%) was higher than $88 \%$ in all tested temperatures.

On the other hand, Pereira et al. (2004) reported lower T. pretiosum emergence when the parasitoid was reared on Plutella xylostella Linnaeus 1758 (Lepidoptera, Plutellidae) eggs. They obtained emergence values (\%) of 73.4, 66.7, 62.9, 84.8, 86.7, 54.8, and 69.2 at same temperatures tested here on $S$. frugiperda eggs. These contrasting results are probably due to intrinsic characteristics of the host eggs that were different in those studies. Bueno (2008) studying biological characteristics of $T$. pretiosum RV on both $P$. includens and A. gemmatalis eggs reported some differences depending on the host eggs where the parasitoid developed. According to the author, this difference is due to the quality of the host egg and the adaptation of the strain/specie of each parasitoid to the specific host egg. Also the differences in the results can be due to differences related to the parasitoid strain that were different in these studies. Therefore, adaptation of a specific strain from a specific region to a pest species need be taken into consideration when selecting the most appropriated parasitoid to be used in a biological control program.

Sex ratio data indicate that $T$. pretiosum can be reared at the tested temperature range without negative effects on this parameter. This is very important in order to keep parasitoid quality for mass releases. Bueno (2008) studying T. pretiosum $\mathrm{RV}$ reared on $A$. gemmatalis and $P$. includens eggs reported that sex ratio changed at the different temperatures. On the other hand, the sex ratio of other strain of T. pretiosum studied by Pratissoli \& Parra (2000) was not altered when reared on T. absoluta eggs at different temperatures. However, when this other strain of $T$. pretiosum was reared on $P$. opercullela eggs, the sex ratios were statistically different with values of 0.83, 0.88, 0.89, 0.99, 0.96, and 0.92 at $18^{\circ} \mathrm{C}, 20^{\circ} \mathrm{C}, 22^{\circ} \mathrm{C}$, $25^{\circ} \mathrm{C}, 30^{\circ} \mathrm{C}$, and $32^{\circ} \mathrm{C}$, respectively (Pratissoli \& Parra 2000). Trichogramma exiguum Pinto \& Platner, 1978 reared on $P$. xylostella eggs had a higher sex ratio than $T$. pretiosum at the same variation of temperature (from $18^{\circ} \mathrm{C}$ to $32^{\circ} \mathrm{C}$ ) (Pereira et. al. 2004). Thus, it shows that sex ratio is variable according to the host, parasitoid strains and/or species and the interaction between parasitoid and host showing that is very important to study these biological characteristics at different situations.

The results regarding the number of parasitoid emerged per egg host indicate that $S$. frugiperda eggs were nutritionally adequate for $T$. pretiosum development, since more than one progeny per egg was recorded in this research.

The values for temperature threshold $(\mathrm{Tb})$ calculated here were slightly lower than those previously reported for different strains of $T$. pretiosum (Pratissoli et al. 2005). Tb was 9.6 when $T$. pretiosum was reared on A. kuehniella eggs and 13.53 when reared on $P$. operculella eggs, respectively (Pratissoli \& Parra 2000). However, the values obtained in this study for thermal constant $(\mathrm{K})$ are similar to those previous published in the literature, from 125.6 to 183.3 for $T$. pretiosum on different host species (Pratissoli \& Parra 2000). A high value of $\mathrm{R}^{2}(96.29 \%)$ indicates how accurate the
Table II. Lifetime parasitism and parasitoid longevity (Mean \pm SE) of $T$. pretiosum RV reared on $S$. frugiperda eggs at different temperatures $\left[18^{\circ} \mathrm{C}\right.$ to $32^{\circ} \mathrm{C}$ temperature, $70 \pm 10 \% \mathrm{RH}, 14 / 10 \mathrm{~h}$ (L:D) photoperiod].

\begin{tabular}{cllll}
\hline $\begin{array}{c}\text { Temperature } \\
{ }^{\circ} \mathrm{C}\end{array}$ & $\begin{array}{c}\text { Total of parasitized } \\
\text { eggs/female }\end{array}$ & \multicolumn{3}{c}{$\begin{array}{c}\text { Longevity } \\
\text { (days) }\end{array}$} \\
\hline 18 & $17.85 \pm 0.70$ b & $17.45 \pm 0.46$ & a \\
20 & $9.95 \pm 0.52$ & bc & $14.05 \pm 0.39$ & ab \\
22 & $11.75 \pm 0.30$ bc & $13.25 \pm 0.25$ & ab \\
25 & $14.80 \pm 0.72$ bc & $9.80 \pm 0.24$ & bc \\
28 & $30.10 \pm 0.95$ & a & $7.45 \pm 0.14$ & c \\
30 & $9.15 \pm 0.57$ bc & $2.95 \pm 0.15$ & d \\
32 & $7.20 \pm 0.40$ c & $2.00 \pm 0.08$ & d \\
\hline
\end{tabular}

Means followed by the same letter in the column are not statistically different according to Tukey test $(\mathrm{P}>0.05)$. Statistics were performed with data transformed by $\sqrt{ }(\mathrm{x}+1)$.

results were in this study. Differences reported from different studies indicate that parasitoid species and/or strains and also host species have great influence on thermal requirements for the genus Trichogramma.

The rhythm of parasitism at different temperatures is a biological characteristic specific for each parasitoid strain or specie reared on each host (Pratissoli \& Parra 2000; Pratissoli \& Parra 2001; Pratissoli et al. 2004). However, similar results to those reported here were previously reported by Pratissoli et al. (2004). They showed that the parasitism of T. pretiosum on $P$. xylostella eggs was concentrated in the first 24 hours under high temperatures, being 16, 12 and 14 parasitized eggs at 25,28 , and $30^{\circ} \mathrm{C}$, respectively. Other authors also reported high parasitism during the first 24 hours when studying different species or strains of Trichogramma and host species (Inoue \& Parra 1998; Resende \& Ciociolla 1996). This behavior might be associated with the lower longevity of the parasitoids when reared under higher temperatures compared with lower temperatures (Inoue 1997). Under higher temperatures the metabolic expenses are also higher; therefore, it is advantageous for the parasitoid to concentrate the parasitism on the first hours of parasitism (Gerling 1972). To have the parasitism concentrated on the first day is a positive feature aiming mass releases in the field. This might guarantee a quick pest control and allow growers to apply herbicides or fungicides shortly after the parasitoid release when it is necessary.

The high total parasitism observed at $28^{\circ} \mathrm{C}$ indicates that this temperature might be ideal for the development of $T$. pretiosum. Similar results were previously found by Zachrisson (1997) and Pratissoli et al. (2004) for different strains of T. pretiosum parasitizing A. gemmatalis and T. absoluta eggs. The highest parasitoid longevity recorded in this research was similar to that reported by Pratissoli et al. (2004) at the same temperature. It is important to point out that despite temperature being an important point to be considered, it is not the only factor influencing insect development, longevity, and other characteristics. Abiotic factors as well as biotic ones might impact the insect biology (Pratissoli \& Parra 2001). 


\section{CONCLUSIONS}

1) The developmental time and the longevity of $T$. pretiosum reared on $S$. frugiperda eggs are inversely correlated to temperature increasing;

2) Emergence of $T$. pretiosum is high ( $\geq 88.9 \%$ ) when reared on $S$. frugiperda eggs, even within a wide range of temperature varying from $18^{\circ} \mathrm{C}$ to $30^{\circ} \mathrm{C}$;

3) Temperatures ranging from $18^{\circ} \mathrm{C}$ to $32^{\circ} \mathrm{C}$ had no impact on sex ratio and number of parasitoids emerged per egg of $S$. frugiperda;

4) The most favorable temperature for $T$. pretiosum development and lifetime parasitism rate on $S$. frugiperda eggs is $28^{\circ} \mathrm{C}$.

Acknowledgments. We are grateful to Dr. Maria Cristina Neves de Oliveira and Dr. Antonio R. Panizzi, Embrapa Soja, for the critical review of the manuscript (This paper was approved for publication by the Editorial Board of Embrapa Soja as manuscript number 16/2008). Thanks are also expressed to Embrapa Soja, CNPq and CAPES for the financial support, which turned this research possible.

\section{REFERENCES}

Botelho, P. S. M. 1997. Eficiência de Trichogramma em campo. p. 303-318. In: Parra, J. R. P. \& R.A. Zucchi (ed) Trichogramma e o controle biológico aplicado. Piracicaba, FEALQ, $324 \mathrm{p}$.

Bourchier, R. S. \& S. M. Smith. 1996. Influence of environmental conditions and parasitoid quality on field performance of Trichogramma minutum. Entomologia Experimentalis et Applicata 80: 461-468.

Bueno, R. C. O. F. 2008. Bases biológicas para utilização de Trichogramma pretiosum Riley, 1879 (Hymenoptera: Trichogrammatidae) para controle de Pseudoplusia includens (Walker, 1857) e Anticarsia gemmatalis Hübner, 1818 (Lepidóptera: Noctuidae) em soja. Tese de doutorado. Escola Superior de Agricultura "Luiz de Queiroz", Universidade de São Paulo, 119 p.

Bueno, R. C. O. F.; J. R. P. Parra; A. F. Bueno \& M. L. Haddad. 2009. Desempenho de Tricogramatídeos como potenciais agentes de controle de Pseudoplusia includens Walker (Lepidoptera: Noctuidae). Neotropical Entomology 38: 389-394.

Cruz, I. \& F. T. Turpin. 1982. Efeito da Spodoptera frugiperda em diferentes estágios de crescimento da cultura de milho. Pesquisa Agropecuária Brasileira 17: 355-359.

Cruz, I.; L. J. Oliveira; A. C. Oliveira \& C. A. Vasconcelos. 1996. Efeito do nível de saturação de alumínio em solo ácido sobre os danos de Spodoptera frugiperda (J.E. Smith) em milho. Anais da Sociedade Entomológica do Brasil 25: 293-297.

Cruz, I. 2002. MIP em milho. Cultivar 43: 36-38.

Diez-Rodriguez, G. I. \& C. Omoto. 2001. Herança de resistência de Spodoptera frugiperda (J. E. Smith) (Lepidoptera: Noctuidae) à lambdacialotrina. Neotropical Entomology 30: 311-316.

Gerling, D. 1972. The developmental biology of Telenomus remus Nixon (Hymenoptera: Scelionidae). Bulletin of Entomological Research 61: 385-388.

Greene, G. L.; N. C. Leppla \& W. A. Dickerson. 1976. Velvetbean caterpillar: a rearing procedure and artificial medium. Journal of Economic Entomology 69: 487-488.

Haddad, M. L.; J. R. P. Parra \& R. C. Moraes.1999. Métodos para estimar os limites térmicos inferior e superior de desenvolvimento de insetos. Piracicaba, FEALQ, 29 p.

Haddad, M. L.; R. C. B. Moraes \& J. R. P. Parra. 1995. MOBAE, Modelos
Bioestatísticos Aplicados à Entomologia. Manual. Piracicaba, ESALQ/ USP, $44 \mathrm{p}$.

Haji, F. N. D.; J. Jimenez Velásquez; E. Bleicher; J. A. Alencar; A. T. Haji \& R. S. Diniz. 1998. Tecnologia de produção massal de Trichogramma spp. Petrolina, Embrapa-CPATSA, 24 p.

Hassan, S. A. 1997. Seleção de espécies de Trichogramma para o uso em programas de controle biológico. p. 183-206. In: Parra, J. R. P. \& R. A. Zucchi (ed) Trichogramma e o Controle Biológico Aplicado. Piracicaba, FEALQ, 324 p.

Inoue, M. S. R. 1997. Bioecologia da traça-dos-cereais, Sitotroga cerealella (Olivier, 1819) e seu controle biológico, em milho armazenado, com Trichogramma pretiosum, Riley, 1879 e Bracon eretor Say, 1857. Dissertação de mestrado. Escola Superior de Agricultura "Luiz de Queiroz”, Universidade de São Paulo, 102 p.

Inoue, M. S. R. \& J. R. P. Parra. 1998. Efeito da temperatura no parasitismo de Trichogramma pretiosum Riley, 1879 sobre ovos de Sitrotroga cerealella (Oliv., 1819). Scientia Agrícola 55: 222-226.

Luginbill, P. 1928. The fall armyworm. Technical Bulletin United States Department of Agriculture, v.34, p.1-91,

Parra, J. R. P.; R. A. Zucchi \& S. Silveira Neto. 1987. Biological control of pests through egg parasitoids of the genus Trichogramma and/ or Trichogrammatoidea. Memórias do Instituto Oswaldo Cruz 82: 153-160.

Parra, J. R. P. 1997. Técnicas de criação de Anagasta kuehniella, hospedeiro alternativo para produção de Trichogramma. p. 121-150. In: Parra, J. R. P. \& R. A. Zucchi (ed.). Trichogramma e o controle biológico aplicado. Piracicaba, FEALQ, 324 p.

Pereira, F. F.; R. Barros; D. Pratissoli \& J. R. P.Parra. 2004. Biologia e exigências térmicas de Trichogramma pretiosum and T. exiguum Pinto \& Platner (Hymenoptera: Trichogrammatidae) criados em ovos de Plutella xylostella (L.) (Lepidoptera: Plutellidae). Neotropical Entomology 33: $1-10$.

Pratissoli, D.; J. C. Zanuncio; U. R. Vianna; J. S.Andrade; T. M. Pinon \& G. S. Andrade. 2005. Thermal requirements of Trichogramma pretiosum and T. acacioi (Hym.: Trichogrammatidae), parasitoids of the avocado defoliator Nipteria panacea (Lep.: Geometridae), in eggs of two alternative hosts. Brazilian Archives of Biology and Technology 48: 523-529.

Pratissoli, D.; F. F. Pereira; R. Barros; J. R. P. Parra \& C. L. T. Pereira. 2004. Parasitismo de Trichogramma pretiosum em ovos da traça-das-crucíferas sob diferentes temperaturas. Horticultura Brasileira 22: 754-757.

Pratissoli, D. \& J. R. P. Parra. 2000. Desenvolvimento e exigências térmicas de Trichogramma pretiosum Riley, criados em duas traças do tomateiro. Pesquisa Agropecuária Brasileira 35: 1281-1288.

Pratissoli, D. \& J. R. P. Parra. 2001. Seleção de linhagens de Trichogramma pretiosum Riley (Hymenoptera: Trichogrammatidae) para o controle das traças Tuta absoluta (Meyrick) e Phthorimaea opercullella (Zeller) (Lepidoptera: Gelechiidae). Neotropical Entomology 30: 277-282.

Resende, D. L. M. C. \& A. I. Ciociolla. 1996. Capacidade de parasitismo de Trichogramma atopovirilia Oatman \& Platner, 1983 (Hymenoptera: Trichogrammatidae) em ovos de Helicoverpa zea (Boddie, 1850) (Lepidoptera: Noctuidae) em diferentes temperaturas. Ciência e Agrotecnologia 20: 421-424.

Scholler, M. \& S. Hassan. 2001. Comparative biology and life tables of Trichogramma evnescens and T. cacoeciae with Ephestia elutella as host at four constant temperatures. Entomologia Experimentalis et Applicata 98: 35-40.

Sparks, A. N. 1979. A review of the biology of the fall armyworm. The Florida Entomologist 62: 83-87.

Smith, S. M. 1996. Biological control with Trichogramma: Advances, successes and potential of their use. Annual Review of Entomology 41: 375-406.

Stein, C.P. \& J. R. P. Parra. 1987. Uso da radiação para inviabilizar ovos de Anagasta kuehniella (Zeller, 1879) visando estudos com Trichogramma spp. Anais da Sociedade Entomológica do Brasil 16: 229-231.

Zachrisson, B. A. 1997. Bioecologia de Trichogramma pretiosum Riley, 1879, para o controle de Anticarsia gemmatalis Hübner, 1818, na cultura da soja. Dissertação de mestrado. Escola Superior de Agricultura “Luiz de Queiroz”, Universidade de São Paulo, 106 p. 